\title{
Empirical Tests Of Optimal Cognitive Distance
}

\section{Stefan Wuyts, Massimo G. Colombo, Shantanu Dutta, and Bart Nooteboom}

\begin{tabular}{|l|l|}
\hline \multicolumn{2}{|l|}{ ERIM REPORT SERIES RESEARCH IN MANAGEMENT } \\
\hline ERIM Report Series reference number & ERS-2004-007-ORG \\
\hline Publication & 2004 \\
\hline Number of pages & 33 \\
\hline Email address corresponding author & b.Nooteboom@fbk.eur.nl \\
\hline Address & Erasmus Research Institute of Management (ERIM) \\
& Rotterdam School of Management / Rotterdam School of Economics \\
& Erasmus Universiteit Rotterdam \\
& P.O.Box 1738 \\
& 3000 DR Rotterdam, The Netherlands \\
& Phone: +31 10 408 1182 \\
& Fax: $\quad+31104089640$ \\
& Email: info@erim.eur.nl \\
& Internet: $\quad$ www.erim.eur.nl \\
\hline
\end{tabular}

Bibliographic data and classifications of all the ERIM reports are also available on the ERIM website: www.erim.eur.nl 


\title{
ERASMUS RESEARCH INSTITUTE OF MANAGEMENT
}

\author{
REPORT SERIES \\ RESEARCH IN MANAGEMENT
}

\begin{tabular}{|c|c|c|}
\hline \multicolumn{3}{|c|}{ BIBLIOGRAPHIC DATA AND CLASSIFICATIONS } \\
\hline Abstract & \multicolumn{2}{|c|}{$\begin{array}{l}\text { This article provides empirical tests of the hypothesis of 'optimal cognitive distance', proposed } \\
\text { by Nooteboom (1999, 2000), in two distinct empirical settings. Variety of cognition, needed for } \\
\text { learning, has two dimensions: the number of agents with different cognition, and differences in } \\
\text { cognition between them (cognitive distance). The hypothesis is that in interfirm relationships } \\
\text { optimal learning entails a trade-off between the advantage of increased cognitive distance for a } \\
\text { higher novelty value of a partner's knowledge, and the disadvantage of less mutual } \\
\text { understanding. If the value of learning is the mathematical product of novelty value and } \\
\text { understandability, it has an inverse-U shaped relation with cognitive distance, with an optimum } \\
\text { level that yields maximal value of learning. With auxiliary hypotheses, the hypothesis is tested } \\
\text { on interfirm agreements between pharmaceutical companies and biotech companies, as well as } \\
\text { on interfirm agreements in ICT industries. }\end{array}$} \\
\hline \multirow{3}{*}{$\begin{array}{l}\text { Library of Congress } \\
\text { Classification } \\
\text { (LCC) }\end{array}$} & $5001-6182$ & Business \\
\hline & $5546-5548.6$ & Office Organization and Management \\
\hline & HD 30.28 & Strategic management \\
\hline \multirow{3}{*}{$\begin{array}{l}\text { Journal of Economic } \\
\text { Literature } \\
\text { (JEL) }\end{array}$} & $\mathrm{M}$ & Business Administration and Business Economics \\
\hline & $\begin{array}{l}\text { M } 10 \\
\mathrm{~L} 2\end{array}$ & $\begin{array}{l}\text { Business Administration: general } \\
\text { Firm Objectives, Organization and Behaviour }\end{array}$ \\
\hline & L 1 & Firm Strategy \\
\hline \multirow{3}{*}{$\begin{array}{l}\text { European Business Schools } \\
\text { Library Group } \\
\text { (EBSLG) }\end{array}$} & $85 \mathrm{~A}$ & Business General \\
\hline & $\begin{array}{l}100 \mathrm{~B} \\
240 \mathrm{~B}\end{array}$ & $\begin{array}{l}\text { Organization Theory (general) } \\
\text { Information Systems Management }\end{array}$ \\
\hline & $270 \mathrm{~A}$ & Strategic management \\
\hline \multicolumn{3}{|c|}{ Gemeenschappelijke Onderwerpsontsluiting (GOO) } \\
\hline \multirow[t]{3}{*}{ Classification GOO } & 85.00 & Bedrijfskunde, Organisatiekunde: algemeen \\
\hline & $\begin{array}{l}85.05 \\
85.08\end{array}$ & $\begin{array}{l}\text { Management organisatie: algemeen } \\
\text { Organisatiesociologie, organisatiepsychologie }\end{array}$ \\
\hline & 85.10 & Strategisch beleid \\
\hline \multirow[t]{3}{*}{ Keywords G0O } & \multicolumn{2}{|c|}{ Bedrijfskunde / Bedrijfseconomie } \\
\hline & \multicolumn{2}{|c|}{ Organisatieleer, informatietechnologie, prestatiebeoordeling } \\
\hline & \multicolumn{2}{|c|}{ Innovatie, netwerken, lerende organisatie, biotechnologie, informatietechnologie } \\
\hline Free keywords & \multicolumn{2}{|c|}{ Alliances, innovation, organizational learning, biotechnology, ICT } \\
\hline
\end{tabular}




\title{
EMPIRICAL TESTS OF OPTIMAL COGNITIVE DISTANCE
}

\author{
Stefan Wuyts*, Massimo G. Colombo**, Shantanu Dutta***, and Bart Nooteboom* \\ * Erasmus University Rotterdam \\ ** Politecnico di Milano, Department of Economics, Management and Industrial Engineering \\ ***University of Southern California and London Business School
}

\begin{abstract}
This article provides empirical tests of the hypothesis of 'optimal cognitive distance', proposed by Nooteboom $(1999,2000)$, in two distinct empirical settings. Variety of cognition, needed for learning, has two dimensions: the number of agents with different cognition, and differences in cognition between them (cognitive distance). The hypothesis is that in interfirm relationships optimal learning entails a trade-off between the advantage of increased cognitive distance for a higher novelty value of a partner's knowledge, and the disadvantage of less mutual understanding. If the value of learning is the mathematical product of novelty value and understandability, it has an inverse- $U$ shaped relation with cognitive distance, with an optimum level that yields maximal value of learning. With auxiliary hypotheses, the hypothesis is tested on interfirm agreements between pharmaceutical companies and biotech companies, as well as on interfirm agreements in ICT industries.
\end{abstract}

key words: alliances, innovation, organizational learning, biotechnology, ICT

areas of study: economics, business, strategy, organization 


\section{EMPIRICAL TESTS OF OPTIMAL COGNITIVE DISTANCE}

\section{Introduction}

Diversity is a crucial condition for learning and innovation, to produce Schumpeterian 'novel combinations', as demonstrated in evolutionary economics (Nelson and Winter 1982). Diversity is associated with the number of agents (people, firms) with different knowledge and/or skills, who are involved in a process of learning or innovation by interaction. However, next to the number of agents involved, a second dimension of diversity is the degree to which their knowledge or skills are different. This yields the notion of 'cognitive distance', based on a constructivist, interactionist view of knowledge (Berger and Luckmann, 1967; Hendriks-Jansen, 1996; Mead, 1934; Nooteboom, 2000; Weick, 1979, 1995). According to this view, people perceive, interpret, understand and evaluate the world according to mental categories (or cognitive frames, or models, cf. Johnson-Laird, 1983), which they have developed in interaction with their physical and social environment. As a result, people see and know the world differently to the extent that their cognition has developed in different conditions (national, regional and organizational culture, customs/habits, social norms/values, education, technologies, markets). This yields the notion of cognitive distance, and the notion of a firm as a 'focusing device', as part of a 'cognitive theory of the firm', proposed by Nooteboom (2000, 2002). We summarize the key features of the theory.

Here, cognition is to be seen in a broad sense, including not only rational evaluation but also emotion-laden value judgements, and heuristics of attribution, inference and decision-making that we know from social psychology (Bazerman, 1998; Tversky and Kahneman, 1983). In a firm, people need to achieve a common purpose, and for this they need some more or less tacit shared ways of seeing and interpreting the world. In view of incentive problems, in monitoring and control, especially in contemporary organizations of more or less autonomous professionals, and the desire for intrinsic next to extrinsic motives (Frey, 2002), people in organizations also need to share more or less tacit values and norms, to align objectives, govern relational risk and to provide a basis for conflict resolution. Elsewhere in this special issue, it is shown that due to uncertainty concerning contingencies of collaboration, and limited opportunities for monitoring, ex ante measures of governance are seldom complete, and need to be supplemented with ex-post adaptation.

Organizational focus, provided by organizational culture, yields an epistemological and normative 'substrate' to achieve this, as basis for shared processes of attribution, mutual adaptation and decision-making. In other words, cognitive distance needs to be restricted for the sake of coordination. Organizational culture incorporates fundamental views and intuitions regarding the relation between the firm and its environment, attitude to risk, the nature of knowledge, the nature of man and of relations between people, which inform content and process of strategy, organizational structure, and styles of decision-making and coordination (Schein, 1985). 
Organizational focus needs to be tight, in the sense of allowing for little ambiguity and variety of meanings and standards, if the productive system of a firm, for the sake of exploitation, is 'systemic', as opposed to 'stand-alone' (Langlois and Robertson, 1995). Exploitation is systemic when there is a complex division of labor, with many elements and a dense structure of relations between them, with tight constraints on their interfaces. An example is an oil refinery. In more standalone systems, elements of the system are connected with few other elements, and connections are loose, allowing for some ambiguity and deviation from standards on interfaces. An example is a consultancy firm. An intermediate system, between systemic and stand-alone, is a modular system. Here, there are also multiple, connected elements, as in the systemic case, but the standards on interfaces allow for variety, where different modules can be plugged into the system.

Organizational focus yields a risk of myopia (in 'group think'): relevant opportunities and threats to the firm are not seen. To compensate for this, firms need outside contacts for 'external economy of cognitive scope' (Nooteboom, 1992). On the basis of different experiences, with different technologies and different markets, and different organizational histories, in other words at some cognitive distance, outside firms perceive, interpret and understand phenomena differently, and this may compensate for organizational myopia. This yields a new purpose for inter-organizational alliances (Nooteboom, 1999), next to the usual considerations, known from the alliance literature (Bleeke and Ernst, 1991; Child and Faulkner, 1998; Contractor and Lorange, 1988; Faulkner, 1995; Geringer and Hebert, 1989; Hagedoorn, 1993; Hagedoorn and Schakenraad, 1994; Killing, 1983, 1988; Mowery, 1988; Ohmae, 1989; Osborn and Baughn, 1990; Porter, 1986).

The different foci of firms entail cognitive distance between firms. In processes of learning and innovation, in interaction between firms, this yields both an opportunity and a problem. The opportunity lies in diversity: the novelty value of a relation increases with cognitive distance. However, mutual understanding decreases with cognitive distance. If effectiveness of learning by interaction is the mathematical product of novelty value and understandability, the result is an inverse- $U$ shaped relation with cognitive distance. Optimal cognitive distance lies at the maximum of the curve. This is illustrated in Figure 1.

Figure 1 about here

In Figure 1, the downward sloping line represents understandability. The upward sloping line represents the novelty value of a relation. The optimal level of cognitive distance from a learning perspective lies in-between very low and very high levels of cognitive distance. The purpose of this article is to conduct empirical tests of this hypothesis of optimal cognitive distance. 


\section{Empirical tests}

The hypothesis concerning 'external economy of cognitive scope' entails that greater uncertainty in an industry, in terms of the volatility of technology and markets, yields a greater need to engage in outside relations with other organizations, to correct for the myopia of organizational focus. Thus, the hypothesis entails that in such industries there will be more outside relations, in interfirm alliances for innovation and technical development. ${ }^{1}$

On the whole, our analysis can be seen as complementary to transaction cost economics (TCE) (Williamson 1975, 1985), by extending it with a perspective of learning. However, some predictions from our analysis would deviate from those of TCE. In particular, TCE argues that uncertainty yields greater risk of opportunism, which needs to be controlled either by hierarchy, or, in hybrid forms of organization, by 'relational governance', in close cooperation. We acknowledge the logic of this argument, but our argument of cognitive distance indicates that for learning too close and durable relations may reduce cognitive distance too much, reducing the learning potential of the relationship. In sum, for generating technological breakthroughs one may need less integration, in hierarchy or relational governance, than suggested by TCE.

Prior research has been consistent with this idea, without, however, explicitly testing it. Powell, Koput and Smith-Doerr (1996) suggest that in turbulent knowledge-intensive industries, where knowledge bases are complex and dispersed, interfirm cooperation is crucial as innovation takes places in networks of partnerships rather than in individual firms. One example is the pharmaceutical industry, where the growth of biotechnology has caused a greater dispersion of technological knowledge throughout the pharmaceutical industry, which has subsequently been the main driver for pharmaceutical firms to engage in alliances with biotechnology firms. The hypothesis of an increased need for alliances under conditions of volatility has further been confirmed by Colombo and Garrone (1998). They analyze the strategies of telecommunication carriers in the early ' 90 s and find that in Internet services and content where technology and demand uncertainty were especially high, the relative rate of alliance formation was higher than in other communication industries characterized by absence of such extreme uncertainty. In addition, in the former industries a large share of the alliances established by telecommunication carriers had an inter-sectoral nature,

\footnotetext{
${ }^{1}$ Real option theory (Dixit and Pindyck, 1994) argues that in an uncertain business environment, there is an opportunity cost of making an irreversible investment expenditure due to the lost option value of waiting for new information to arrive. Therefore, with great uncertainty firms may refrain from transaction-specific investments to avoid the risk of incurring sunk costs if unpredicted contingencies occur and conserve flexibility and ease of adjustment (Pindyck, 1988 and 1993). With all else equal, the need for hierarchical governance structures is reduced. In this sense, real option theory and the cognitive theory of the firm have coincident predictions. Nonetheless, contrary to real option theory, the cognitive theory of the firm also has predictions as to the identity of alliance partners (see infra).
} 
linking them with firms from a variety of industries; this suggests that external economies of cognitive scope may have played a key role in alliance formation.

Now we turn to our more explicit tests of the hypothesis of optimal cognitive distance. We provide two independent tests in two different empirical settings. The first one focuses on vertical $R \& D$ agreements in which large pharmaceutical firms source technological knowledge from small upstream biotechnology firms. This test focuses exclusively on the technological dimension of cognitive distance. The second one concerns agreements (both horizontal and vertical) in information and communication technology (ICT) industries. Even though such agreements have diverse objectives, for reasons that will be explained later mutual learning in the technological and/or organizational spheres plays a crucial role. This second test considers both the technological and organizational dimensions of cognitive distance. By focusing on two different empirical settings, we hope to provide a richer perspective on the different aspects of cognitive distance.

In the first test, we focus on a pharmaceutical firm's overall technological cognitive distance with its biotechnology partners, and its impact on the generation of technological innovations. The organizational cognitive distance dimension is less relevant in this setting, as all agreements take place between small innovative biotechnology firms on the one hand and large established pharmaceutical firms on the other hand. In other words, there is minimal variation across agreements in organizational cognitive distance. For pharmaceutical firms, the major objective of these upstream $\mathrm{R} \& \mathrm{D}$ agreements is to access external knowledge bases and not to miss out on promising technological developments. For the biotechnology firms, the primary objective is not assimilating new technological knowledge but rather gaining legitimacy and experience (Baum, Calabrese and Silverman, 2000) as well as gaining access to marketing and production capabilities once the drug has been developed (Powell, Koput and Smith-Doerr, 1996). While in this test we have a direct measure of technological innovation, we do not have a direct measure of cognitive distance. Rather, we assume that the more pharmaceutical firms cooperate with the same partners over time in their agreement portfolio, the lower will be the average cognitive distance with their partners. This assumption is consistent with an earlier finding that cognitive distance decreases as interaction is more frequent (Lewicki and Bunker, 1996; McAllister, 1995). With the subsidiary hypothesis that such ongoing collaboration reduces cognitive distance, we can test the derived hypothesis that technological innovation has an inverse $\mathrm{U}$-shaped relation with the extent to which agreements are spread over a larger number of different partners (henceforth referred to as 'partner dispersion'). This hypothesis is confirmed. Details on the data and the estimation procedure are given in the next section.

For a second test, we employ data from the ARPA database developed at Politecnico di Milano on alliances established in the ' 80 s in ICT industries. As was said earlier, the scope of activities and the objectives of the agreements considered in this test vary in a way that we are unable to observe. Nevertheless, the early ' 80 s were a very turbulent period in ICT industries, as they were 
marked by the introduction of major innovations and radical changes in the institutional environment connected with the liberalization of telecommunication services. As a result, firms were forced to upgrade their technological capabilities and adopt new business models. As a consequence, we assume here that the assimilation of new technological and organizational knowledge through the interaction with other firms was an important determinant of alliance formation (albeit not the unique and sometimes not even the most important one), independently of the specific nature of the agreements under consideration. Here, we do have a more direct measure of technological cognitive distance, as well as a set of indicators for organizational cognitive distance. Unfortunately, we lack a measure of innovative performance. With the subsidiary hypothesis that firms chose the partners of their collaborative relations so as to maximize the probability of success, and that this latter depends on the effectiveness of mutual learning processes, we can test the derived hypothesis that the likelihood of alliance formation has an inverse $\mathrm{U}$-shaped relation with cognitive distance. That hypothesis is also partially confirmed. Details on the data and the estimation procedure are given in a following section.

In short, we provide two tests in different settings that highlight different aspects of the optimal cognitive distance hypothesis. The test in the pharmaceutical industry studies vertical $R \& D$ agreements and relies on a narrow interpretation of cognitive distance (restricted to the technological dimension). The test in the ICT sector studies agreements with different domains of activity, adopting a more comprehensive interpretation of cognitive distance (including both the technological and organizational dimensions). In both tests, we assume learning to be central to the agreements under study.

\section{Agreement portfolios in the pharmaceutical industry - Technological Cognitive Distance}

For a first empirical test of the hypothesis on cognitive distance, we constructed a database on interfirm cooperation in the pharmaceutical industry. In this industry, knowledge bases are complex and dispersed, which is an incentive for firms to develop portfolios of agreements with other firms in order to access external knowledge bases (Dutta and Weiss, 1997; Powell, Koput and Smith-Doerr, 1996). Such R\&D agreements are vehicles for learning and they enhance a firm's external economy of cognitive scope, which in turn enhances that firm's ability to come up with unique technological innovations.

While it is generally accepted, both in academia and in practice, that R\&D agreement portfolios contribute to a firm's innovative success, one of the most important strategic concerns in the pharmaceutical industry remains how to optimally develop a portfolio of $\mathrm{R} \& \mathrm{D}$ agreements (Bamford and Ernst, 2001). Despite the importance of such portfolios, only few empirical studies 
have studied the implications of their composition (Dutta and Weiss, 1997; Wuyts, Dutta and Stremersch, 2004). The one portfolio characteristic that deserves special attention in view of the theory of cognitive distance is the extent to which firms distribute their agreements over different partners. High levels of such 'partner dispersion' (as operationalized by the ratio of the total number of different partners over the total number of agreements) are assumed to be associated with high cognitive distance between the focal firm and its total set of partners. If a firm's portfolio of agreements is characterized by low levels of partner dispersion, this firm tends to cooperate more frequently with the same partners. ${ }^{2}$ Such repeated interaction allows for the creation of relationshipspecific heuristics and shared mental models that reduce cognitive distance, and, hence, facilitate the transfer of the tacit components of knowledge (Polanyi, 1966; Uzzi, 1997). This is crucial in technology-intensive science-based industries such as the pharmaceutical industry, as novel scientific discoveries are seldom codified (Zucker, Darby and Armstrong, 2002). However, at very low levels of partner dispersion (frequent cooperation with the same partners) technological cognitive distance can decrease so much that the novelty of knowledge flows is insufficient to generate technological innovations. Recent work on relational embeddedness in economic sociology provides additional support for the argument that cooperating too frequently with the same partners over time lowers the novelty value of information flows (Uzzi, 1997). Hence, firms should seek the optimal level of cognitive distance in their portfolio of $R \& D$ agreements that allows for the transfer of tacit knowledge but maintains a level of novelty of knowledge flows.

In the context of the pharmaceutical industry, we therefore expect that a firm's ability to come up with novel technologies is a function of the level of partner dispersion in its portfolio of R\&D agreements. It is important to note that this is a derived hypothesis, as our dataset does not allow for a direct measure of technological cognitive distance. Rather, we rely on the assumption that partner dispersion is an indicator of cognitive distance.

Hypothesis 1: The likelihood of coming up with novel technologies in the pharmaceutical industry is highest for firms with a portfolio of $\mathrm{R} \& \mathrm{D}$ agreements at medium levels of partner dispersion.

\section{Empirical context}

Our first test focuses on the pharmaceutical industry, a technology-intensive industry where interfirm cooperation is considered to be crucial for success (Arora and Gambardella, 1990; Baum, Calabrese and Silverman, 2000; Powell, 1998). Interfirm cooperation in the pharmaceutical industry

\footnotetext{
${ }^{2}$ We acknowledge that the duration of the agreements would be useful additional information to reflect the frequency of interaction. Unfortunately, alliance databases typically do not provide this information. By focusing on only upstream $R \& D$ agreements covering one $R \& D$ project, we have tried to minimize potential biases caused by our lack of duration data.
} 
boomed with the rise of biotechnology. Biotechnology includes all techniques by which humans control biological processes of breeding organisms for some specific purposes (Amburgey, Dacin and Singh, 1996). While traditional biotech systematically controls and alters the environments of large colonies of bacteria and induces them to multiply in large quantities (e.g., fermentation), new biotech consists of techniques of recombinant DNA and cell fusion, which allows scientists to manipulate the inner structures of micro-organisms. The discovery of recombinant DNA (by Cohen and Boyer in 1973) and cell fusion (by Kohler and Milstein in 1975) gave birth to the modern biotech industry. In the eighties, a series of other events influenced the role of biotechnology in the pharmaceutical industry (Amburgey, Dacin and Singh, 1996; Zucker, Darby and Brewer, 1994). In 1980 the Supreme Court ruled that genetically engineered micro-organisms were patentable. In 1982 the FDA approved the first major biotech-drug for marketing, Genentech's human insuline. From the mid-eighties on, pharmaceutical firms started to engage in $R \& D$ agreements with small innovative biotechnology firms. Such interfirm agreements provide biotechs with access to capital as well as to capabilities for getting approval for drugs and for commercialization and distribution of approved drugs. For pharmaceutical firms, on the other hand, such $R \& D$ agreements provide access to external knowledge bases that might yield important new opportunities for technological advance. Our database of interfirm agreements starts in 1985, i.e., at the inception of alliance activity in this industry.

\section{Data description}

We constructed a database consisting of information on (1) R\&D agreements between pharmaceutical firms and biotechnology firms, (2) new drugs developed by these pharmaceutical firms and that are technologically unique, and (3) different firm characteristics (see also Wuyts, Dutta and Stremersch, 2004). More specifically, we combined data from three different sources.

First, the R\&D alliance data were collected from Recombinant Capital, a consulting firm experienced in the biotechnology industry. Their recap database covers all R\&D agreements between pharmaceutical firms and biotech firms from 1985 until today. In order to allow for a fine-grained test of the cognitive distance hypothesis, we confine our attention to 18 major pharmaceutical firms that have all developed large and technologically diversified agreement portfolios over the last decades. While these portfolios are similar in size and technological diversity (i.e., the first dimension of diversity as discussed at the outset), there is substantial variance - over time and between firms - in the extent to which firms ally with the same partners. Note that we only consider R\&D agreements (no joint ventures, mergers, or acquisitions) that in general cover one specific R\&D project. While this may be a limitation of our dataset, our focus on $R \& D$ agreements lends more credence to our assumption that the individual agreements are approximately of equal length and strength. Altogether, the pharmaceutical firms in our sample were involved in $571 \mathrm{R} \& \mathrm{D}$ agreements during the observation period. 
Second, we need a measure of technological innovation. Information on new drugs that are technologically unique is collected from the drug approval list of the Federal Drug Administration (FDA). Not only does the FDA provide information on all new drugs approved in each year, it also distinguishes technologically unique drugs from drugs that are based on prior technology. More precisely, the FDA assigns a chemical type to each newly approved drug. Only drugs of chemical type 1 represent a new technology different from the established technologies, as they involve an "active ingredient that has never been marketed before". An example of such a chemical type 1 drug is Novartis' Zometa drug, approved in 2001, which involves a completely new active ingredient (zoledronic acid) for treating the deterioration of cancer patients' inner bone structure (hypercalcemia of malignancy). Drugs based on a previously approved active ingredient are not considered a technological innovation. The FDA provides this detailed information only for drugs approved from 1991 on. The pharmaceutical firms from our sample received approval for 64 drugs of chemical type 1 in the period 1991-2000.

Third, we collected firm-specific variables from the Compustat database.

\section{Variables and measures}

Technological innovation. Our dependent variable is a $0 / 1$ variable indicating whether or not firm $i$ generates a drug of chemical type 1 in year $t$, i.e., a drug that is technologically unique.

Partner dispersion. We construct an index, $N P_{i t} / N A_{i t}$, where $N P_{i t}$ denotes the total cumulative number of different partners in firm i's agreement portfolio from 1985 up to year $t$, and $N A_{i t}$ denotes the total cumulative number of R\&D agreements in firm $i$ 's agreement portfolio from 1985 up to year $t$. The index varies in the interval $[0 ; 1]$ in which values close to 1 represent a portfolio where agreements are signed with many different partners (indicating that overall cognitive distance is large), while values close to 0 represent portfolios with a very limited number of different partners (indicating that overall cognitive distance is small). In our sample, values of partner dispersion varied from 0.40 to 1.00 . $($ mean $=0.87$; s.d. $=0.10)$. In our model we lag partner dispersion with one period. Note that the cumulative character, as well as the lag structure, strengthen the causality of our findings in that technological innovation at time $t$ is influenced by the level of partner dispersion of a firm's portfolio of agreements in the period $1985-(t-1)$.

\section{Control variables}

While we are particularly interested in the effect of repeated partnering on the probability of technological innovation, there are several other variables we should control for.

$R \& D$ expenditures. In the first place, we control for the firm's own expenditures in research and development. We expect that the more firms spend on research and development, the more they are innovative. 
Firm size. The effect of firm size on innovation is unclear, especially in industries where firm boundaries become vague due to large numbers of interfirm linkages (Pisano 1990). Also, we focus only on large firms. Yet, we include firm size as a control variable.

Time trend and industry shocks. Prior studies have found a negative time trend due to the growing intensity of competitiveness in the biotechnology industry (e.g., Zucker, Darby and Brewer 1994). We also include year dummy variables, in order to control for industry shocks that may have occurred in this volatile industry.

Prior technological innovations. A final control variable is a firm's stock of prior unique technological innovations. This variable is a count variable that equals the cumulative number of approved technologically innovative drugs for firm $i$ from 1991 up to year $t$. This variable not only captures experience effects, but also covers the internal processes and structures that are set in place in order to develop innovative drugs. We expect that a firm's track record of prior technological innovations enhances the probability that it will come up with a new technological innovation in year $t$.

We lagged all variables with one period, except for the trend and the year dummies. Table 1 summarizes the explanatory variables of the first empirical test; descriptive statistics are reported in Table 2. Table 3 summarizes the expected effects.

\section{Empirical test}

Given the binary nature of the dependent variable, we estimated a logit model. ${ }^{3}$ As independent variables we include repeated partnering and its quadratic term, as well as the control variables described above. Table 4 reports the results.

In view of the panel data structure of our data, we studied whether our results are biased by unobserved heterogeneity. More specifically, we re-estimated the logit model using a latent class modelling technique (e.g., Kamakura and Russell, 1989; Wedel and DeSarbo, 1994), in order to identify the number of different underlying latent segments among the pharmaceutical firms. Latent class modelling is a discrete mixture approach that allows one to capture unobserved heterogeneity by identifying different classes of firms in the sample that are internally homogeneous, but that differ from other classes in terms of the effects of the covariates. Based on Schwarz' Bayesian Information Criterion (1978), we found that the optimal number of latent segments equals 1 , which indicates that the extent of unobserved heterogeneity is small. This comes as no surprise given our focus on a narrow set of firms that are very similar. As an additional check, we included firm dummy variables, corresponding with a fixed effects specification, and found none of these dummies to be significant except for two: Pharmacia (at 5\% level) and Smithkline (close to significance) seem to be

\footnotetext{
${ }^{3}$ The underlying assumption of a logistic cumulative distribution function does not affect the results: we found very similar results under alternative specifications, such as a probit specification.
} 
significantly better at achieving technological advance for reasons not covered by our explanatory variables. In view of the limited number of observations and the insignificance of the other firm effects, we include these two dummy variables in the final model. Including other portfolio descriptors, such as portfolio size and technological diversity, did not affect the results either. Finally, we tested the robustness of our results using different lag structures and, again, found our results to be robust.

As mentioned above, we also included year dummy variables in order to capture time-specific heterogeneity. We find only one of these dummies to be significant, namely for 1996 . We include this dummy in the final model. We estimated two logit models, one with and one without the partner dispersion terms (see Table 4). Our main interest goes to the significant inverted $U$ effect of partner dispersion in Model 2 (main term: $\beta=58.537 ; p<0.05$; quadratic term: $\beta=-33.908 ; p<0.05$ ), in support of hypothesis $1 .{ }^{4}$ Our results indicate that technological innovations are most likely to occur at intermediate levels of partner dispersion, i.e., in firms that strike a balance between engaging in different $R \& D$ agreements with the same partners and avoiding lock-in with a too narrow set of partners. Of the control variables, $R \& D$ expense has the expected positive effect $(\beta=0.001 ; \mathrm{p}<0.01)$. Surprisingly, the prior stock of technological innovations does not affect the probability of developing a new technological innovation. Further exploratory analyses show that this effect turns positive and significant when excluding the firm dummy variables, which is explained by both Pharmacia and Smithkline's strong ability to develop technological innovations. Further in-depth research may reveal why these two firms are so successful in developing drugs that are technologically unique. We find a negative time trend $(\beta=-0.108 ; \mathrm{p}<0.10)$, which may be an indication of increased competition as the industry developed. The two firm dummies and the one year dummy we retained are all significant or close to significance at $10 \%$ level. The difference in log likelihood with Model 1 (which doesn't contain the partner dispersion effects) is significant at 5\% level, underscoring the explanatory power of partner dispersion and thus, indirectly, of technological cognitive distance.

Concluding, our first empirical test provides indirect support for the technological cognitive distance hypothesis. We followed prior work that points to the decrease in cognitive distance that results from repeated interaction between exchange partners (Lewicki and Bunker, 1996; McAllister, 1995), and assumed that repeatedly allying with the same partners in a firm's portfolio of agreements lowers overall cognitive distance. Our analysis in the pharmaceutical industry reveals that a portfolio composition characterized by intermediate levels of repeated partnering, i.e., at intermediate levels of cognitive distance, is associated with the highest probability of unique technological innovation.

\footnotetext{
${ }^{4}$ Note that the optimum $(0.85)$ lies within the range of values in our dataset $([0.4 ; 1])$, which implies that we can interpret the significance of the main and quadratic term as indication of an inverted $U$ effect.
} 


\section{Alliance formation in ICT industries - Technological and Organizational Cognitive Distance}

The second empirical test was conducted in ICT industries (i.e. semiconductor, data processing, and telecommunications) and considered alliance formation in the 1981-1986 period. In such industries the early 1980s were marked by high volatility of technology and markets. Major innovations occurred, such as the IBM PC introduced in late 1981; and technological competition was aggressive both between incompatible platforms within a particular segment (e.g. the DOS, CP/M and Apple platforms in the microcomputer segment) and across different industry segments (e.g. between microcomputers and minicomputers, between supermini and mainframes). In addition, the break-up of ATT radically modified the institutional environment of telecommunication services, with important implications for the competitive scenario in all ICT industries. Technological competencies and business models that had dominated the earlier decade rapidly became obsolete (e.g. the notions of "open architecture" and "modular design" rapidly gained ground, to the detriment of reliance on proprietary standards and vertical integration). ${ }^{5}$ Accordingly, it is reasonable to assume that in the period under scrutiny, inter-organizational learning and (both technological and organizational) innovation were key drivers of firms' alliance strategy.

In this setting, we expect that not only technological cognitive distance but also organizational cognitive distance exerted a crucial influence on the choice of alliance partners. In fact, to the extent that mutual learning is an important motivation for the establishment of an alliance, the success of the alliance will require an optimal level of technological and organizational cognitive distance. Note that the former aspect may be less relevant than the latter one in the current context where contrary to the first empirical test, alliances cover a diversity of activities (e.g. production, marketing and sale) rather than only $R \& D$, and may have various objectives (e.g. rationalization of production, entry into a new market, definition of a new standard). In fact, moderate differences between alliance partners in strategic characteristics that mold their mental maps and organizational routines may be a source of novelty, enhance organizational learning and favor assimilation of new business models (as compared to low differences). On the contrary, very large differences limit mutual understanding and hence learning, while they substantially increase the likelihood of conflicts within an alliance. ${ }^{6}$ Medium levels of understandability in terms of organizational culture and strategic behavior may aid in attaining smooth and fruitful cooperation. ${ }^{7}$ In short, we expect that the

\footnotetext{
${ }^{5}$ For a thorough discussion of technological competition in ICT industries in the period under study and its implications for industry dynamics, see for instance Bresnahan and Greenstein (1999), Langlois and Robertson (1992).

${ }^{6}$ This latter aspect is particularly relevant in horizontal alliances with a learning objective, as they bear the risk that the partner firms, that may well be competitors outside of the boundaries of their alliance, end up in a learning race that inhibits smooth cooperation (Doz and Hamel, 1998).

${ }^{7}$ For a similar view of inter-organizational learning in a different context, see Vermeulen and Barkema (2001).
} 
likelihood of alliance formation is thus highest at medium levels of technological as well as organizational cognitive distance between firms.

Hypothesis 2: The likelihood of alliance formation in ICT industries is highest for firms that have medium levels of technological and organizational cognitive distance.

\section{Data description}

The data on alliances used in this paper are provided by the ARPA database developed at Politecnico di Milano. ARPA surveyed agreements in ICT industries between 1980 and 1986. ICT industries account for a substantial share of the total number of agreements concluded by firms and the rate of formation of new alliances peaked in the mid 1980s (see Hagedoorn and Schakenraad, 1992). ARPA includes data on 2,014 cooperative agreements established by 1,177 independent partners (for further information on the ARPA database, see Cainarca, Colombo and Mariotti, 1992; Colombo, 1995). As ARPA relies on secondary sources of information (the international financial press and sector magazines), it suffers from a series of problems that typically affect such sources. For our purposes the main shortcoming is lack of information on the objectives of alliances (see Glaister and Buckley 1996 for a discussion of this problem). This is a source of observational noise, as we are unable to separate agreements for which mutual learning, especially in the technology sphere, is a key motivation, and cognitive distance (in particular, technological cognitive distance) crucially influences the choice of partners, from other agreements for which cognitive distance may play a more modest role. In addition, ARPA suffers from selection biases. In particular, press coverage is probably biased towards large firms and glamorous events. So alliances between small firms, alliances of limited strategic importance, and alliances between firms that are already involved in several collaborations with each other (unless such later alliances are of great strategic importance) are likely to be underrepresented in the ARPA database. This notwithstanding, ARPA provides a reasonably accurate coverage of the alliance activity in ICT industries all over the world of international companies of medium and large size. In particular, there is no reason to believe that the above mentioned sample selection biases substantially influence the relation between the likelihood of sample firms having established one or more alliances between each other in the period under scrutiny and cognitive distance between them. ${ }^{8}$

\footnotetext{
${ }^{8}$ In this paper we assume that cognitive distance decreases with the number of partnerships established by two firms with each other. As was said above, press coverage may be somewhat biased towards novel events. With all else equal, the first alliance between any two firms is more likely to be included in the ARPA database than the nth one. Therefore, there may indeed be a selection bias in our data set of alliances, as we may miss some alliances between cognitively close firms. Note however that as will be explained later, the binary dependent variable we use in the econometric analysis does not discriminate according to the number of alliances between two firms, as it only distinguishes cooperating and non-cooperating pairs of firms. Furthermore, the period under scrutiny is relatively short and our measures of cognitive distance are quite sticky over time (on this aspect see also footnote 10). Hence, cross-firm differences in cognitive distance are likely to be much larger than differences over time relating to a given pair of firms.
} 
In this study, we consider alliances established in 1981-1986 between 67 out of the world's largest 150 firms that operated in ICT industries. Such firms comply with two criteria: i) data relating to organizational and financial characteristics (i.e. sales, R\&D expenditures, profits, distribution of sales by industry) were available for the entire period under scrutiny, and ii) firms were also represented in the database on corporate US patent activity set up at the University of Reading. The Reading database records the patents granted by the US patent office to 784 large firms that together account for over $46 \%$ of all patents granted in the US between 1969 and 1995. Each patent is classified by the type of technological activity with which it is primarily associated, using a classification scheme derived from the US patent class system (for a fuller discussion of these data and their classification see Cantwell, 1993).

Taking the above-mentioned 67 firms, there are a possible 2,211 pairwise combinations between them. Our basic unit of analysis consisted of variables constructed across these 2,211 pairs of firms.

\section{Variables and measures}

\section{Alliance formation}

We model the likelihood of firms $i$ and $j(i, j=1, \ldots, 67 ; i \neq j)$ establishing one or more alliances with each other in the 1981-1986 period. More precisely, the dependent variable equals 0 if the two firms under consideration did not cooperate with each other; otherwise it equals 1 independently of the number and nature of the collaborative relations. The set of covariates includes indicators of (technological and organizational) cognitive distance between firms and control variables.

\section{Measures of cognitive distance}

As was said earlier, cognitive distance has different dimensions. While in the previous test we strictly focused on technological cognitive distance, we now also account for organizational cognitive distance.

Accordingly, we distinguish between two sets of indicators. The first group consists of variables that measure differences in organizational and strategic characteristics of firms. We assume that the organization and strategy of firms are the result of a historical, cumulative process that shapes the way firms interpret and react to the external word. It follows that different strategic and organizational characteristics mirror the presence of different mental models, organizational routines, corporate culture, and management style. In particular, we consider differences between firms in size, with SIMILARSIZE being an inverse measure of size differentials between firms, diversification ( $\triangle D I V E R S I F$ and $\triangle S C O P E$ ), and profit margins ( $\triangle R O S$ ). On the one hand, large, widely diversified firms generally exhibit a larger managerial hierarchy with several intermediate managerial layers, more decentralization and formalization of decision authority, and greater specialization of managerial tasks than their smaller counterparts that operate in one (or a small number of) 
business(es). ${ }^{9}$ In addition, they rely to a much larger extent on standardization of tasks and financial controls rather than strategic controls to cope with agency problems within the managerial hierarchy (see Eisenhardt, 1985; Hoskisson and Hitt, 1988). On the other hand, high profit margins are indicative of market power; accordingly, firms with high profit margins generally follow a strategy based on product differentiation and non-price competitive factors (e.g brand, customer care). On the contrary, low profit margins are typical of firms that operate in commodity-like businesses characterized by price competition; under such circumstances, product standardization aimed at capturing scale economies and tight cost control are far more important for competitive success. Size and profit margins are measured by the mean values of sales and returns on sales in the 1981-1986 period, respectively. Differences in the extent of diversification between firms are measured by two indices: $\triangle D I V E R S I F$ is the difference between the mean values of the Utton diversification index based on the 2-digit SIC classification, while $\triangle S C O P E$ reflects differences as to the distribution of firms' sales within ICT industries. In particular, we consider three industries - semiconductor, data processing, and telecommunications - and again use the Utton diversification index.

We argue that if firms are quite close in the strategy space, with the four indicators of cognitive distance that measure size, diversification, and profit margins taking similar values, they are likely to adopt similar business models and have similar mental maps, organizational routines, corporate culture and management style. Under such circumstances, there will not be much to learn from each other. If organizational cognitive distance is very large, organizational learning will be difficult, even though potentially valuable to firms; in fact, lack of mutual understanding will result in large coordination costs. In addition, as firms have different visions of the world, the likelihood of conflicts between alliance partners will be greater. Therefore, we expect the probability of cooperation between any two firms first to increase and then to decrease with greater values of the variables that measure organizational cognitive distance.

The second group of variables focuses on technology-based indicators. More specifically, we consider differences in both the intensity of the resources devoted by firms to R\&D activity and the pattern of allocation of such resources across technological fields. With all else equal, cognitive distance will be large if firms focus on different technologies. It will also increase with the different research intensity of their operations. $\Delta R \& D$ is the difference between the average values in the period under scrutiny of the $\mathrm{R} \& \mathrm{D}$ to sales ratio of firms. CRTA is the Pearson correlation index of the distribution across 31 technological classes related to ICT of the revealed technological advantages (RTA) of each firm relative to the other sample firms. The RTA of a firm in a particular technological field is defined as the firm's share in that field of the US patents granted to all companies in the study,

\footnotetext{
${ }^{9}$ On the organizational peculiarities of large, diversified firms see for instance the seminal work by Chandler (1962). Colombo and Delmastro (1999) analyze a large sample of Italian manufacturing firms, showing that the number of managerial layers and the delegation of decision-making power increase with an increase of firm size.
} 
relative to its overall share of all US patents granted to these companies. The RTA index varies around one, such that a value greater than one suggests that a firm is comparatively specialized in the technology in question, given its overall innovative performance. Positive values of CRTA indicate similarity of the pattern of relative technological specialization of firms, as it appears from the distribution of their patent activity across technological fields. ${ }^{10}$ In accordance with the existence of an "optimal" technological cognitive distance between firms, we predict positive and negative coefficients for the linear and squared terms of both $\triangle R \& D$ and $C R T A$ respectively.

\section{Other variables}

We introduced into the econometric model two additional sets of variables. The first group takes into account differences between firms as to their sector of operation and home country. In order to control for the latter aspect, we defined five dummy variables: USA, EUR, JAP, USA-EUR, and USA-JAP. As to the former aspect, SAMESECTOR equals 1 when two firms have the same primary sector of activity; COMMONSECTOR equals 1 if the two firms under scrutiny operate in one or more common sectors (except when such common sector is the primary sector of activity of both firms; in that case SAMESECTOR=1 and COMMONSECTOR=0). So the baseline in the model is given by pairs composed of a European firm and a Japanese firm with no overlapping operations. Differences in sector of activity and home country clearly influence cognitive distance between firms. However, they also reflect other aspects that are likely to affect firms' propensity towards alliance, namely the incentives for rival firms to teaming up due to competitive reasons and the alleged different propensity towards establishment of alliances on the part of firms located in different geographic regions (e.g. the greater propensity of Japanese firms, the smaller propensity of US firms).

The second set of control variables takes into account factors that have no bearing on cognitive distance, but were found by previous studies to greatly affect the rate of alliance formation (for a discussion of such issue and related literature see for instance Colombo, 1995; Sakakibara,

\footnotetext{
${ }^{10}$ More precisely, denoting by $\mathrm{P}_{\mathrm{kj}}$ the number of US patents granted in technological field $k$ to firm $j$, then the RTA index for each firm in that field is defined as follows: $\mathrm{RTA}_{\mathrm{kj}}=\left(\mathrm{P}_{\mathrm{kj}} / \Sigma_{\mathrm{j}} \mathrm{P}_{\mathrm{kj}}\right) /\left(\Sigma_{\mathrm{k}} \mathrm{P}_{\mathrm{kj}} / \Sigma_{\mathrm{kj}} \mathrm{P}_{\mathrm{kj}}\right)$. Note that the assumption is made here that in spite of the fact that the RTAs are based on data on patent activity, their distribution across technological fields reflects the relative distribution of both codified and tacit technological knowledge. In other words, the distributions across technological fields of firms' tacit and codified knowledge are closely correlated. For a more detailed discussion of CRTA see Cantwell and Barrera (1998), Cantwell and Colombo (2000). Such indicator is conceptually very close to Jaffe's (1989) indicator of technological proximity. The main advantage is that use of RTA values allows to control for the fact that firms' propensity to patent varies systematically across technologies. The main drawback of this patent-based measure of cognitive distance is that it must be based on a sufficiently large number of patents. So its use is confined to firms with substantial patent activity observed over a sufficiently long period of time. This is also the reason why RTAs are based on firms' patent activity in the whole period for which data are available (i.e. 1969-1995, see again Cantwell and Colombo, 2000). We are aware that this choice may raise an endogeneity problem, as firms' patent activity in the 19821995 period may be influenced by alliances established in the 1981-1986 period. Note however that a preliminary investigation showed that the patterns of technological specialization of sample firms are quite stable over time (on this topic see also Patel and Pavitt, 1997). Therefore, we assume that differences of CRTA across different pairs of firms are much larger then differences over time relating to the same pairs of firms.
} 
2002). In particular, for each pair of firms we consider the sum of their size, profit margins, $R \& D$ intensity, and diversification.

The definition of the explanatory variables is illustrated in Table 5; in Table 6 we report descriptive statistics, while Table 7 illustrates the predicted sign of the coefficients of such variables and the rationale underlying our expectations.

\section{Empirical test}

The results of the estimates of logit models of alliance formation are illustrated in Table 8. Model I is the benchmark: it includes only control variables that are unrelated to cognitive distance between firms. In accordance with the results of previous studies, the likelihood of establishing an alliance is found to increase with firm size, diversification, and R\&D intensity; in contrast, firms' profit margins have no effect on alliance formation. In Model II we introduce a second set of control variables that account for firms' home country and sector of operation. Quite unsurprisingly, such variables turn out to be highly significant, as is apparent by the value of the LR test $\left(\chi_{(7)}^{2}=61.8\right)$. The positive, statistically significant coefficient of SAMESECTOR indicates that firms that have the same primary sector of activity are more likely to collaborate than firms with no overlapping operations. In addition, inter-region alliances are generally found to be less likely than intra-region ones; alliances between US firms are the exception, possibly due to the deterrence effect of stricter anti-trust policy in the US than in other geographical areas (at least up to 1984 when the National Cooperative Research Act was issued, see Katz and Ordover, 1990).

For our purposes, the most interesting findings are provided by Models III and IV, in which we introduced measures of technological and organizational cognitive distance, first in a linear specification (Model III) and then in a quadratic one (Model IV). First of all, the quadratic specification of cognitive distance adds considerable explanatory power to the model (see Model IV); in fact, the twelve coefficients of the cognitive distance variables are found to be jointly significant by a LR test $\left(\chi_{(12)}^{2}=28.6\right.$, significant at $\left.1 \%\right)$. In accordance with our hypothesis, this is mainly due to the six squared terms introduced in Model IV $\left(\chi_{(6)}^{2}=17.9\right.$, significant at $\left.1 \%\right)$. On the contrary, the additional explanatory power of the linear specification is modest; the six indicators of cognitive distance introduced in Model III are found to be jointly significant by a LR test, but only at $10 \%$ $\left(\chi_{(6)}^{2}=10.9\right)$.

Let us now consider in greater detail the estimates of Model IV. Contrary to our predictions, the two technology-related indicators of cognitive distance (i.e. $\triangle R \& D$ and $C R T A$ ) have no significant effect on the likelihood of firms entering into cooperative relations with each other. We find greater support for the indicators that reflect strategic and organizational differences between firms. In fact, 
three out of the four indicators have the expected inverse U-shaped relationship ${ }^{11}$ with propensity towards alliance, namely SIMILARSIZE, $\triangle R O S$ and $\triangle D I V E R S I F$, with both the linear and quadratic terms being significant at conventional confidence levels. Contrary to expectations, the coefficients of $\triangle S C O P E$ are not significant, even though they have the predicted signs.

To sum up, after controlling for the effects of other factors (notably, the industry in which firms operate and their home country), we find some support for the hypothesis that in ICT industries there is an optimal organizational cognitive distance between firms, while the likelihood of alliance formation seems not to be a function of technological cognitive distance. Apparently, when selecting an alliance partner in this particular empirical context, firms care more about differences in business models. Technological distance seems to be less relevant. We will interpret this finding as well as the findings from the first empirical test in the concluding section.

\section{Limitations and Conclusions}

This article has provided two tests of hypotheses derived from the central hypothesis of optimal cognitive distance, that the outcome of learning or innovation by interaction is related to cognitive distance according to an inverse U-shaped curve.

The first derived hypothesis was based on a combination of the basic hypothesis of optimal cognitive distance with a second hypothesis that cognitive distance decreases with increased frequency of interaction. This yielded the hypothesis of an inverse U-shaped relation between the probability of unique technological innovation and the extent to which firms ally with the same partners over time. That hypothesis was tested on data in the pharmaceutical industry, and was supported. The first empirical test concerned only upstream $R \& D$ agreements that were very similar to one another, and was restricted to the technological dimension of cognitive distance. The major limitation of this test was our lack of a direct measure of cognitive distance. Further research is required to corroborate our assumption that the overall cognitive distance a firm faces increases with increases in its agreement portfolio's partner dispersion. The major managerial implication of this test is that cognitive distance may guide firms in their efforts to compose an optimal R\&D agreement portfolio, i.e., a portfolio that enhances the probability to achieve unique technological advance. How to optimally compose such a portfolio is a major concern for managers in pharmaceutical firms (Bamford and Ernst, 2001; Powell, 1998). We find that in this complex industry, a relatively high level of partner dispersion can be recommended, but that firms should avoid mere maximization of partner dispersion: we argue that very high levels of partner dispersion create an almost unbridgeable cognitive gap and hence lowers the probability of generating technological innovations.

\footnotetext{
${ }^{11}$ Note that also here we find that the optimum is within the range of values in the data set, which implies that the
} 
The second derived hypothesis was based on the auxiliary hypothesis that the likelihood of alliance formation increases with the expected payoff in terms of technological and/or organizational innovation. This yields the derived hypothesis that the likelihood of an alliance for innovation between any two firms has an inverse U-shaped relation with cognitive distance. That hypothesis was tested on data on both horizontal and vertical alliances in ICT industries, based on a broader interpretation of cognitive distance that also takes into account its organizational dimension. We found partial support. In particular, while technology-related measures of cognitive distance were found not to have any significant effect on the probability of allying, several indicators that reflect differences in firms' organizational and strategic characteristics proved to have the expected inverse U-shaped relation.

Interestingly, we find that in the context of alliances in ICT industries organizational cognitive distance was more important than technological cognitive distance, whereas in the context of upstream pharma-biotech cooperation technological distance prevails. There are several considerations for an explanation why organizational aspects turned out to be more important than technological ones in ICT industries. First, as data were provided by secondary sources of information, the precise motivations of the alliances under consideration remain unobserved. While there is reason to believe that mutual learning is an important motivation of (most of) such agreements, the joint development of new technological capabilities may be of crucial concern only in a subset of them. For those for which it is not (e.g. alliances aimed at eliminating excess production capacity, obtaining access to a new market, setting a standard), technological cognitive distance between firms will play a negligible role. Second, as was indicated in the theoretical introduction, when a technology is systemic, as is the case in ICT, then, almost by definition, organizational issues are more important than in the case of stand-alone technology, as in biotechnology. Third, according to innovation theory there is a cycle of innovation, where, after a stage of volatility, technology converges on a 'dominant design'. Then demand and competition increase, and attention shifts to organization for commercialization (market entry, access to distribution channels) and efficient production, which may in turn lead to a dominant design in organization (Abernathy, 1978; Abernathy \& Clark, 1985; Abernathy \& Utterback, 1978). In the period under examination, ICT industries were largely in that stage of shifting from technology to organization, whereas the pharmaceutical industry was clearly in a stage of high volatility. In sum, our explanation of the outcome is that in addition to the presence of an observational noise, in ICT industries learning is more oriented towards organization than technology, because the technology involved is systemic, requiring attention to coordination and integration of parts in ICT systems; and in the observation period the focus of innovation has shifted from technology to the design and implementation of new business models.

significance of the quadratic term is an indication of an inverted $U$ effect. 
Both tests are indirect, in opposite ways. In the first test we had a direct measure of innovative output, but not of cognitive distance. In the second test the reverse applied: we had several measures of cognitive distance, but not of innovative output. Clearly, for a direct test we need both a measure of cognitive distance and a measure of innovative output, and requisite control variables. That yields a priority for further research. However, the indirect tests presented in this article lend credence to the hypothesis of optimal cognitive distance, and yield promise for a direct test. Another direction for future research would be to study how the location of 'optimal' cognitive distance varies for firms with different levels of absorptive capacity (Cohen and Levinthal, 1990). Going one step further, one could endogenize absorptive capacity, allowing it to evolve over time for one and the same firm, and study the interaction over time between cognitive distance and absorptive capacity.

The implications of the hypothesis, if further confirmed, are several. It yields further arguments against integration of firms, in a merger or acquisition, in favor of alliances between firms that maintain their independence, in addition to familiar arguments from the alliance literature. Integration would yield reduced cognitive distance, resulting in lack of diversity for the sake of learning and unique technological advance. Thus, the hypothesis of optimal cognitive distance yields a correction on the argument from transaction cost economics that favors integration for the sake of governance, in case of transaction-specific investments and uncertainty about contingencies in the execution of agreements. We do not deny the relevance of that argument, but there may be an overriding argument against integration, to maintain cognitive distance. The hypothesis also goes against the argument from Langlois and Robertson (1995) and Chesbrough and Teece (1996) that when a production system is systemic, integration is needed to align innovation in different parts of the system, to maintain systemic coherence. Here also, we recognize the relevance of the argument, for innovation that is not 'architectural' (Henderson and Clark, 1990). However, architectural innovation entails the break-up of present systemic configuration, and, here again, the need for sufficient cognitive distance may yield an overriding counter-argument (as was, in fact, acknowledged by Langlois and Robertson).

The results of this study may contribute to an understanding of a variety of phenomena in interfirm collaboration. It may, for example, contribute to an understanding of the recent phenomenon that the well-known Japanese vertical structures of keiretsu, e.g. in the car industry, are being disintegrated or loosened. Keiretsu were characterized by tight, durable relations between endproducers and main ('first tier') suppliers. These relations yield several advantages, e.g. on the basis of reduced cognitive distance for efficient collaboration. However, they used to entail exclusiveness, where suppliers were banned from supplying to end producers in competing keiretsu, in order to prevent spillover from extensive knowledge pooling inside the keiretsu. This exclusiveness reduces the diversity of knowledge needed for innovative performance. To allow for more diversity, including larger cognitive distance, suppliers are now permitted, or even encouraged, to also supply outside the 
keiretsu. Spillover is increasingly seen to matter less since the change of knowledge is now so fast as to reduce the risk of it. When knowledge has changed by the time a competitor has absorbed and implemented it for competition, spillover risk drops out (Nooteboom, 1998). However, this is only a conjecture that would need testing against other possible reasons for the disintegration of keiretsu. Concluding, we provide two indirect tests of the cognitive distance hypothesis in two very different empirical settings. Our findings may serve as a stimulus for direct tests and more fine-grained research into the role of cognitive distance, from the perspective of a cognitive theory of the firm. 
Figure 1: Optimal cognitive distance

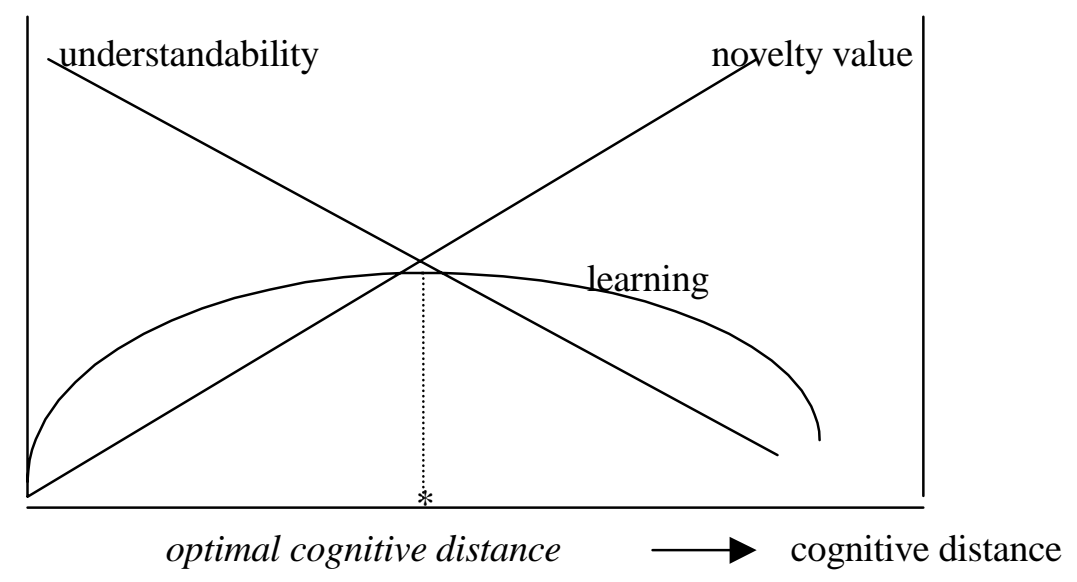


Table 1 - Explanatory variables, empirical test 1

\begin{tabular}{ll}
\hline \hline Variable & \multicolumn{1}{c}{ Operationalization } \\
\hline PARTNER & $\begin{array}{l}\text { Partner dispersion is an indicator variable for the cognitive distance that characterizes } \\
\text { a firm's cumulative portfolio of R\&D agreements. This variable equals the ratio of the } \\
\text { firm's total number of different partners over its total number of agreements. The } \\
\text { variable is lagged with one period. }\end{array}$ \\
PRIORINNOV & $\begin{array}{l}\text { This variable equals the number of firm } i \text { 's prior technological innovations, i.e., the } \\
\text { number of prior chemical type } 1 \text { drugs approved by the FDA. }\end{array}$ \\
FIRMSIZE & The number of employees $(* 1000)$ as provided by Compustat. \\
R\&D & The R\&D expenses as provided by Compustat (billion US dollar). \\
TREND & This variable ranges from 1991 to 2000. \\
D & Dummy variable that equals 1 in the year 1996, else 0. \\
D & Dummy variable that equals 1 when firm $i$ is Pharmacia, else 0. \\
D & Dummy variable that equals 1 when firm $i$ is Smithkline, else 0. \\
\hline \hline
\end{tabular}


Table 2 - Descriptive statistics, empirical test 1

\begin{tabular}{lrrrr}
\hline \hline & \multicolumn{1}{c}{ Mean } & Std. Dev. & Min. & Max. \\
\hline PARTNER DISPERSION & 0.872 & 0.098 & 0.4 & 1 \\
PRIORINNOV & 1.933 & 2.633 & 0 & 12 \\
FIRMSIZE & 43.241 & 28.540 & 0.631 & 151.9 \\
R\&D & 1111.67 & 730.931 & 0.008 & 4435 \\
\hline \hline
\end{tabular}


Table 3 - Predicted sign of the coefficients of the explanatory variables, empirical test 1

\begin{tabular}{|c|c|c|}
\hline Variable & $\begin{array}{l}\text { Predicted } \\
\text { effect }\end{array}$ & Rationale \\
\hline $\begin{array}{l}\text { PARTNER DISPERSION } \\
\text { (PARTNER DISPERSION) }^{2}\end{array}$ & $\begin{array}{l}+ \\
-\end{array}$ & $\begin{array}{l}\text { Basic "cognitive distance" argument in combination with working } \\
\text { hypothesis: "Partner dispersion increases cognitive distance". }\end{array}$ \\
\hline PRIORINNOV & + & Experience effect. \\
\hline FIRMSIZE & $+/-$ & $\begin{array}{l}\text { Effect of firm size in prior literature has been positive, negative and non- } \\
\text { significant. }\end{array}$ \\
\hline $\mathbf{R} \& \mathbf{D}$ & + & R\&D expenses aid in the development of technological innovation. \\
\hline TREND & - & Intensified competition in the pharmaceutical industry. \\
\hline$D_{1996}$ & / & Control variables - no expectations regarding directional effect. \\
\hline D PHARMACIA & I & \\
\hline D $_{\text {SMITHKLINE }}$ & I & \\
\hline
\end{tabular}


Table 4: Estimation results, empirical test 1

DEPENDENT VARIABLE: LIKELIHOOD OF TECHNOLOGICAL INNOVATION

\begin{tabular}{|c|c|c|c|}
\hline & & $I$ & II \\
\hline$\overline{\mathbf{a}_{1}}$ & PARTNER DISPERSION & I & $\begin{array}{l}58.537 \\
(35.296)^{* *}\end{array}$ \\
\hline $\mathbf{a}_{2}$ & 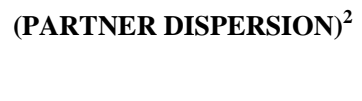 & / & $\begin{array}{l}-33.908 \\
(20.466)^{* *}\end{array}$ \\
\hline $\mathbf{a}_{3}$ & PRIORINNOV & $\begin{array}{l}0.058 \\
(0.075)\end{array}$ & $\begin{array}{l}0.034 \\
(0.076)\end{array}$ \\
\hline $\mathbf{a} 4$ & FIRMSIZE & $\begin{array}{l}-0.014 \\
(0.009)\end{array}$ & $\begin{array}{l}-0.013 \\
(0.009)\end{array}$ \\
\hline a5 & R\&D & $\begin{array}{l}0.001 \\
0.000^{* * *}\end{array}$ & $\begin{array}{l}0.001 \\
(0.000)^{* * * *}\end{array}$ \\
\hline $\mathbf{a}_{6}$ & TREND & $\begin{array}{l}-0.089 \\
0.059\end{array}$ & $\begin{array}{l}-0.108 \\
(0.061)^{*}\end{array}$ \\
\hline $\mathbf{a}_{7}$ & $D_{1996}$ & $\begin{array}{l}0.878 \\
(0.582)\end{array}$ & $\begin{array}{l}0.921 \\
(0.604)\end{array}$ \\
\hline $\mathbf{a}_{8}$ & D PHARMACIA & $\begin{array}{l}3.267 \\
(1.117)^{* * * *}\end{array}$ & $\begin{array}{l}3.234 \\
(1.127)^{* * * *}\end{array}$ \\
\hline a9 & D $_{\text {SMITHKLINE }}$ & $\begin{array}{l}1.022 \\
(0.820)\end{array}$ & $\begin{array}{l}1.247 \\
(0.881)\end{array}$ \\
\hline $\mathbf{a}_{\mathbf{0}}$ & Constant & $\begin{array}{l}-0.583 \\
(0.750)\end{array}$ & $\begin{array}{l}-25.288 \\
(15.071)^{*}\end{array}$ \\
\hline & log-likelihood & -96.866 & -93.841 \\
\hline & n. of observations & 174 & 174 \\
\hline & LR test (d.f) & $33.91(7) * * *$ & $6.05(2)^{* *}$ \\
\hline & Mc Fadden R-squared & 0.149 & 0.172 \\
\hline & \multicolumn{3}{|c|}{$\begin{array}{l}\text { Legend } \\
* \mathrm{p}<0.10 ; * * \mathrm{p}<0.05 ; * * * \mathrm{p}<0.01 \text {. Standard errors or degrees of freedom } \\
\text { between parentheses. Squared terms are indicated by the suffix " } 2 \text { ". } \\
\text { Significance of hypothesized effects is based on one-tailed test, all other } \\
\text { effects are based on two-tailed tests. }\end{array}$} \\
\hline
\end{tabular}


Table 5 - Explanatory variables, empirical test 2

\begin{tabular}{|c|c|}
\hline Variable & Operationalization \\
\hline CRTA & $\begin{array}{l}\text { Value of the Pearson correlation index between the distributions of the Revealed } \\
\text { Technological Advantages }{ }^{\text {a }} \text { of firms across } 31 \text { technological fields related to } \\
\text { Information and Communication Technologies. }\end{array}$ \\
\hline$\Delta \mathbf{R} \& \mathbf{D}$ & $\begin{array}{l}\text { Difference between the average values of the R\&D to sales ratio of firms in the 1981- } \\
\text { ' } 86 \text { period. }\end{array}$ \\
\hline SIMILARSIZE & $\begin{array}{l}\text { Ratio between the average values of total sales of the smaller firm and that of the } \\
\text { larger firm in any pairwise combination of sample firms in the 1981-' } 86 \text { period. }\end{array}$ \\
\hline$\Delta \mathbf{R O S}$ & $\begin{array}{l}\text { Difference between the average values of the returns on sales of firms in the 1981-' } 86 \\
\text { period }\end{array}$ \\
\hline$\triangle$ DIVERSIFICATION & $\begin{array}{l}\text { Ratio of the difference between the average values of the Utton diversification index } \\
\text { (two-digit SIC classification) of firms to the sum of such values in the 1981-' } 86 \\
\text { period. }\end{array}$ \\
\hline$\triangle \mathrm{SCOPE}$ & $\begin{array}{l}\text { Ratio of the difference between the average values of the Utton diversification index } \\
\text { within Information and Communication Technologies (i.e. semiconductor, data } \\
\text { processing, and telecommunication) of firms to the sum of such values in the 1981-'86 } \\
\text { period. }\end{array}$ \\
\hline SAMESECTOR & $\begin{array}{l}\text { Dummy variable: it equals } 1 \text { if firms have the same primary sector of activity in } \\
\text { Information and Communication Technologies. }\end{array}$ \\
\hline COMMONSECTOR & $\begin{array}{l}\text { Dummy variable: it equals } 1 \text { if a) firms are in one or more common sectors in } \\
\text { Information and Communication Technologies and b) SAMESECTOR equals } 0 .\end{array}$ \\
\hline USA & Dummy variable: it equals 1 if a pair of firms is composed of two US firms. \\
\hline EUR & Dummy variable: it equals 1 if a pair of firms is composed of two European firms. \\
\hline JAP & Dummy variable: it equals 1 if a pair of firms is composed of two Japanese firms. \\
\hline USA-EUR & $\begin{array}{l}\text { Dummy variable: it equals } 1 \text { if a pair of firms is composed of a US firm and a } \\
\text { European firm. }\end{array}$ \\
\hline USA-JAP & $\begin{array}{l}\text { Dummy variable: it equals } 1 \text { if a pair of firms is composed of a US firm and a Japanese } \\
\text { firm. }\end{array}$ \\
\hline SIZE & $\begin{array}{l}\text { Average value of total sales of firms in the 1981-' } 86 \text { period (billion US } \$, 1980 \\
\text { prices). }\end{array}$ \\
\hline ROS & Average value of the returns on sales of firms in the 1981-'86 period. \\
\hline $\mathbf{R} \& \mathbf{D}$ & Average value of the R\&D to sales ratio of firms in the 1981-' 86 period. \\
\hline DIVERSIFICATION & $\begin{array}{l}\text { Average value of the Utton diversification index (two-digit SIC classification) of firms } \\
\text { in the 1981-' } 86 \text { period. }\end{array}$ \\
\hline SCOPE & $\begin{array}{l}\text { Average value of the Utton diversification index within Information and } \\
\text { Communication Technologies (i.e. semiconductor, data processing, and } \\
\text { telecommunication) of firms in the } 1981 \text {-' }^{\prime} 86 \text { period. }\end{array}$ \\
\hline
\end{tabular}

Legend

a) The revealed technological advantage $\left(\mathrm{RTA}_{\mathrm{ij}}\right)$ of firm $i$ in technological class $j$ is calculated as follows. Let $\mathrm{P}_{\mathrm{ij}}$ be the number of US patents granted to firm $i$ in technological class $j$ over the period 1969-'95. Then RTA $\mathrm{A}_{\mathrm{ij}}=$ $\left(\mathrm{P}_{\mathrm{ij}} / \sum_{\mathrm{j}} \mathrm{P}_{\mathrm{ij}}\right) /\left(\sum_{\mathrm{i}} \mathrm{P}_{\mathrm{ij}} / \Sigma_{\mathrm{ij}} \mathrm{P}_{\mathrm{ij}}\right), i=1, \ldots, 67 ; j=1, \ldots, 31$. 
Table 6 - Descriptive statistics, empirical test 2

\begin{tabular}{|c|c|c|c|c|}
\hline & Mean & Std. Dev. & Min. & Max. \\
\hline CRTA & 0.004 & 0.268 & -0.646 & 0.976 \\
\hline$\Delta R \& D$ & 0.032 & 0.026 & 0 & 0.142 \\
\hline SIMILARSIZE & 0.408 & 0.272 & 0.004 & 0.999 \\
\hline$\Delta$ ROS & 0.033 & 0.030 & 0 & 0.219 \\
\hline$\triangle$ DIVERSIFICATION & 0.234 & 0.169 & 0 & 0.617 \\
\hline$\triangle \mathrm{SCOPE}$ & 0.178 & 0.143 & 0 & 0.458 \\
\hline SAMESECTOR & 0.408 & 0.492 & 0 & 1 \\
\hline COMMONSECTOR & 0.420 & 0.494 & 0 & 1 \\
\hline USA & 0.254 & 0.435 & 0 & 1 \\
\hline EUR & 0.086 & 0.280 & 0 & 1 \\
\hline JAP & 0.035 & 0.185 & 0 & 1 \\
\hline USA-EUR & 0.308 & 0.462 & 0 & 1 \\
\hline USA-JAP & 0.200 & 0.400 & 0 & 1 \\
\hline SIZE & 6.739 & 9.362 & 0.395 & 79.230 \\
\hline ROS & 0.073 & 0.043 & -0.117 & 0.220 \\
\hline$R \& D$ & 0.126 & 0.041 & 0.032 & 0.300 \\
\hline DIVERSIFICATION & 3.520 & 1.192 & 2 & 8.125 \\
\hline SCOPE & 2.881 & 0.738 & 2 & 5.361 \\
\hline
\end{tabular}


Table 7 - Predicted sign of the coefficient of the explanatory variables, empirical test 2

\begin{tabular}{|c|c|c|}
\hline Variable & Predicted effect & Rationale \\
\hline CRTA & + & \\
\hline CRTA2 & - & $\begin{array}{l}\text { Basic "technological cognitive distance" argument in } \\
\text { combination with working hypothesis: "technological } \\
\text { cognitive distance is negatively related to the } \\
\text { correlation between the Revealed Technological } \\
\text { Advantages of firms in ICT-related technological } \\
\text { fields" }\end{array}$ \\
\hline$\Delta \mathbf{R} \& \mathbf{D}$ & + & Id. \\
\hline$\Delta \mathbf{R} \& \mathbf{D} 2$ & - & \\
\hline SIMILARSIZE & + & Id. \\
\hline SIMILARSIZE2 & - & \\
\hline$\Delta \mathbf{R O S}$ & + & Id. \\
\hline$\Delta \mathrm{ROS2}$ & - & \\
\hline$\triangle$ DIVERSIFICATION & + & Id. \\
\hline$\triangle$ DIVERSIFICATION2 & - & \\
\hline$\triangle \mathrm{SCOPE}$ & + & Id. \\
\hline$\triangle$ DIVERSIFICATION & - & \\
\hline SAMESECTOR & + & $\begin{array}{l}\text { Horizontal cooperation is driven by competitive } \\
\text { motives. }\end{array}$ \\
\hline COMMONSECTOR & + & $\begin{array}{l}\text { Horizontal cooperation is driven by competitive } \\
\text { motives. }\end{array}$ \\
\hline USA & $?$ & $\begin{array}{l}\text { US firms have lower propensity towards alliances. } \\
\text { Intra-region alliances are more likely than inter-region } \\
\text { ones. }\end{array}$ \\
\hline EUR & + & $\begin{array}{l}\text { Intra-region alliances are more likely than inter-region } \\
\text { ones. }\end{array}$ \\
\hline JAP & + & $\begin{array}{l}\text { Intra-region alliances are more likely than inter-region } \\
\text { ones. }\end{array}$ \\
\hline USA-EUR & - & US firms have lower propensity towards alliances. \\
\hline USA-JAP & - & US firms have lower propensity towards alliances. \\
\hline
\end{tabular}

Legend

For the sake of synthesis control variables unrelated to cognitive distance are not considered. 
Table 8 - Estimation results, empirical test 2

\section{DEPENDENT VARIABLE: LIKELIHOOD OF ALLIANCE FORMATION}

\begin{tabular}{|c|c|c|c|c|c|}
\hline & & $I$ & II & III & $I V$ \\
\hline \multirow{2}{*}{$\mathbf{a}_{0}$} & Constant & -6.621 & -7.021 & -7.086 & -7.964 \\
\hline & & $(0.512)^{* * *}$ & $(0.597)^{* * * *}$ & $(0.610)^{* * *}$ & $(0.682)^{* * * *}$ \\
\hline \multirow[t]{2}{*}{$\mathbf{a}_{1}$} & SIZE & 0.059 & 0.063 & 0.069 & 0.078 \\
\hline & & $(0.006)^{* * *}$ & $(0.006)^{* * *}$ & $(0.007)^{* * *}$ & $(0.008)^{* * *}$ \\
\hline \multirow[t]{2}{*}{$\mathbf{a}_{2}$} & ROS & 1.315 & 2.496 & 2.358 & 0.908 \\
\hline & & -1.679 & -1.763 & -1.759 & -1.853 \\
\hline \multirow[t]{2}{*}{$\mathbf{a}_{3}$} & R\&D & 11.737 & 13.753 & 14.069 & 14.912 \\
\hline & & $(1.663)^{* * *}$ & $(1.808)^{* * *}$ & $(1.975)^{* * *}$ & $(2.106)^{* * *}$ \\
\hline \multirow[t]{2}{*}{$\mathbf{a}_{4}$} & DIVERSIFICATION & 0.082 & 0.049 & 0.090 & 0.100 \\
\hline & & -0.057 & -0.062 & -0.068 & -0.068 \\
\hline \multirow[t]{2}{*}{$\mathbf{a}_{5}$} & SCOPE & 0.753 & 0.611 & 0.611 & 0.575 \\
\hline & & $(0.090)^{* * *}$ & $(0.114)^{* * *}$ & $(0.116)^{* * *}$ & $(0.117)^{* * *}$ \\
\hline \multirow[t]{2}{*}{$\mathbf{a}_{6}$} & SAMESECTOR & & 0.611 & 0.595 & 0.615 \\
\hline & & & $(0.281)^{* *}$ & $(0.291)^{* *}$ & $(0.293)^{* *}$ \\
\hline \multirow[t]{2}{*}{$\mathbf{a}_{7}$} & COMMONSECTOR & & 0.457 & 0.488 & 0.482 \\
\hline & & & -0.289 & -0.298 & -0.300 \\
\hline \multirow[t]{2}{*}{ as } & USA & & -0.220 & -0.291 & -0.172 \\
\hline & & & -0.279 & -0.284 & -0.288 \\
\hline \multirow[t]{2}{*}{ a9 } & EUR & & 1.208 & 1.073 & 1.003 \\
\hline & & & $(0.290)^{* * *}$ & $(0.297)^{* * *}$ & $(0.303)^{* * *}$ \\
\hline \multirow[t]{2}{*}{$\mathbf{a}_{10}$} & JAP & & 1.033 & 1.020 & 1.156 \\
\hline & & & $(0.347)^{* * *}$ & $(0.360)^{* * *}$ & $(0.366)^{* * *}$ \\
\hline \multirow[t]{2}{*}{$\mathbf{a}_{11}$} & USA-EUR & & -0.424 & -0.496 & -0.537 \\
\hline & & & -0.272 & $(0.277)^{*}$ & $(0.281)^{*}$ \\
\hline \multirow[t]{2}{*}{$\mathbf{a}_{12}$} & USA-JAP & & 0.013 & & 0.118 \\
\hline & & & -0.258 & & -0.265 \\
\hline \multirow[t]{2}{*}{$\mathbf{a}_{13}$} & CRTA & & & 0.169 & 0.054 \\
\hline & & & & -0.264 & -0.327 \\
\hline \multirow[t]{2}{*}{$\mathbf{a}_{14}$} & CRTA2 & & & & 0.600 \\
\hline & & & & & -0.694 \\
\hline \multirow[t]{2}{*}{$\mathbf{a}_{15}$} & $\Delta \mathbf{R} \& \mathbf{D}$ & & & -3.197 & -7.649 \\
\hline & & & & -2.856 & -7.491 \\
\hline \multirow[t]{2}{*}{$\mathbf{a}_{16}$} & $\Delta \mathbf{R} \& \mathbf{D} 2$ & & & & 35.502 \\
\hline & & & & & -71.647 \\
\hline \multirow[t]{2}{*}{$\mathbf{a}_{17}$} & SIMILARSIZE & & & 0.611 & 2.702 \\
\hline & & & & $(0.275)^{* *}$ & $(1.160)^{* * *}$ \\
\hline $\mathbf{a}_{18}$ & SIMILARSIZE2 & & & & -2.170 \\
\hline & & & & & $(1.126)^{* *}$ \\
\hline $\mathbf{a}_{19}$ & $\Delta$ ROS & & & 0.996 & 16.241 \\
\hline & & & & -2.512 & $(7.113)^{* *}$ \\
\hline $\mathbf{a}_{20}$ & $\triangle \mathrm{ROS2}$ & & & & -134.847 \\
\hline & & & & & $(62.659)^{* *}$ \\
\hline $\mathbf{a}_{21}$ & $\triangle$ DIVERSIFICATION & & & -0.517 & 2.784 \\
\hline & & & & -0.455 & $(1.514)^{* *}$ \\
\hline $\mathbf{a}_{22}$ & $\triangle$ DIVERSIFICATION2 & & & & -6.318 \\
\hline & & & & & $(2.757)^{* *}$ \\
\hline $\mathbf{a}_{23}$ & $\triangle \mathrm{SCOPE}$ & & & -0.723 & 0.139 \\
\hline & & & & -0.534 & -1.757 \\
\hline $\mathbf{a}_{24}$ & $\triangle \mathrm{SCOPE2}$ & & & & -2.317 \\
\hline & & & & & -4.025 \\
\hline & log-likelihood & -753.80 & -722.90 & -717.42 & -708.74 \\
\hline & n. of observations & 2211 & 2211 & 2211 & 2211 \\
\hline & LR test (d.f) & $191.7(5) * * *$ & $61.8(7) * * *$ & $10.9(6) *$ & $17.9(6) * * *$ \\
\hline & & & & & $28.6(12) * * *$ \\
\hline & Mc Fadden R-squared & 0.113 & 0.149 & 0.156 & 0.166 \\
\hline
\end{tabular}

Legend

$* \mathrm{p}<0.10 ; * * \mathrm{p}<0.05$;*** $\mathrm{p}<0.01$. Significance of hypothesized effects is based on one-tailed test, all other effects are based on two-tailed tests. Standard errors or degrees of freedom between parentheses. Squared terms are indicated by the suffix "2".The second LR test in column IV relates to the null hypothesis that the twelve coefficients of the cognitive distance variables are equal to null. 


\section{References}

Abernathy, W.J., 1978. The Productivity Dilemma: Roadblock to Innovation in the Automobile Industry. Johns Hopkins University Press, Baltimore.

----- Utterback, J.M., 1978. Patterns of Industrial Innovation. Technology Review 81 (june/july), 41 - 47.

---- Clark, K.B., 1985. Innovation: Mapping the Winds of Creative Destruction. Research Policy 14, 3 22.

Amburgey, T.L., Dacin, T., Singh, J.V., 1996. Learning Races, Patent Races, and Capital Races: Strategic Interaction and Embeddedness within Organizational Fields. In: Joel A.C.Baum and Jane E. Dutton (eds), Advances in Strategic Management 3, The Embeddedness of Strategy. Jai Press Inc., London.

Arora, A., Gambardella, A., 1990. Complementarity and External Linkages: The Strategies of the Large Firms in Biotechnology. Journal of Industrial Economics 38 (4), 361-379.

Bamford, J., Ernst, D., 2001. Managing an Alliance Portfolio. The McKinsey Quarterly 3, 29-39.

Baum, J.A.C., Calabrese, T., Silverman, B.S., 2000. Don't Go It Alone: Alliance Network Composition and Start-ups' Performance in Canadian Biotechnology. Strategic Management Journal 21 (3), 267-294.

Bazerman, M., 1998. Judgement in Managerial Decision-Making. Wiley, New York.

Berger, P., Luckmann, T., 1967. The Social Construction of Reality. Doubleday, New York.

Bleeke, J., Ernst, D., 1991. The Way to Win in Cross--Border Alliances. Harvard Business Review November/December, 127--135.

Bresnahan, T.F., Greenstein, S., 1999. Technological Competition and the Structure of the Computing Industry. The Journal of Industrial Economics 47, 1-40.

Cainarca, G.C., Colombo, M.G., Mariotti, S., 1992. Agreements Between Firms and the Technological Life Cycle Model: Evidence from Information Technology. Research Policy 21, 45-62.

Cantwell, J.A., 1993. Corporate Technological Specialisation in International Industries. In M.C.

Casson and J. Creedy (eds.), Industrial Concentration and Economic Inequality: Essays in Honour of Peter Hart. Edward Elgar, Aldershot.

----- Barrera, M.P., 1998. The Localisation of Corporate Technological Trajectories in the Interwar Cartels: Cooperative Learning Versus an Exchange of Knowledge. Economics of Innovation and New Technology 6 (Spring), 257-290.

----- Colombo, M.G., 2000. Technological and Output Complementarities: Interfirm Cooperation in Information Technology Ventures. Journal of Management and Governance 4, 117-147.

Chandler, A.D., 1962. Strategy and Structure. MIT Press, Cambridge MA.

Chesbrough, H.W., Teece, D.J., 1996. When is Virtual Virtuous? Organizing for Innovation. Harvard Business Review Jan./Feb., 65 - 73. 
Child, J., Faulkner, D., 1998. Strategies of Cooperation, Oxford University Press, Oxford.

Cohen, M.D., Levinthal, D.A., 1990. Absorptive Capacity: A New Perspective on Learning and Innovation. Administrative Science Quarterly 35, 128 - 52.

Colombo, M.G., 1995. Firm Size and Cooperation: The Determinants of Cooperative Agreements in Information Technology Industries. International Journal of the Economics of Business 2, 3-29.

----, Delmastro, M., 1999. Some Stylized Facts on Organization and its Evolution. Journal of Economic Behavior and Organization 40(3), 255-274.

----, Garrone, P., 1998. Common Carriers Entry into Multimedia Services. Information Economics and Policy 10, 77-105.

Contractor, F.J., Lorange, P., 1988. Cooperative Strategies in International Business. Lexington Books, Lexington MA.

Dixit, A.K., Pindyck, R.S., 1994. Investment Under Uncertainty. Princeton University Press, New Jersey.

Doz, Y.L., Hamel, G., 1998. Alliance Advantage: The Art of Creating Value Through Partnering. Harvard College.

Dutta, S., Weiss, A.M., 1997. The Relationship Between a Firm's Level of Technological Innovativeness and Its Pattern of Partnership Agreements. Management Science 43 (3), 343-356.

Eisenhardt, K.M., 1985. Control: Organizational and Economic Approaches. Management Science 31 (2), 134-149.

Faulkner, D., 1995. International Strategic Alliances -- Cooperating to Compete. McGraw-Hill, London.

Frey, B.S., 2002. What Can Economists Learn from Happiness Research? Journal of Economic Literature 40 (2), 402-435.

Geringer, M.J., Hebert, L., 1989. Control and Performance of International Joint Ventures. Journal of International Business Studies 20 (2), 235-254.

Glaister, K.W., Buckley, P.J., 1996. Strategic motives for international alliance formation. Journal of Management Studies 33, 301-332.

Hagedoorn, J. 1993. Understanding the Rationale of Strategic Technology Partnering:

Interorganizational Modes of Cooperation and Sectoral Differences. Strategic Management Journal 14, 371-385.

----, Schakenraad, J., 1992. Leading Companies and Networks of Strategic Alliances in Information Technologies. Research Policy 21, 163-190.

----, ---- 1994. The Effect of Strategic Technology Alliances on Company Performance. Strategic Management Journal 15, 291-309.

Henderson, R.M., Clark, K.B., 1990. Architectural Innovation: The Reconstruction of Existing Product Technologies and the Failure of Established Firms. Administrative Science Quarterly 35, 9-30. 
Hendriks-Jansen, H., 1996. Catching Ourselves in the Act -- Situated Activity, Interactive Emergence, Evolution and Human Thought. MIT press, Cambridge MA.

Hoskisson, R. E., Hitt, M. A. 1988. Strategic control systems and relative r\&d investment in large multiproduct firms, Strategic Management Journal, 9, 605-621.

Jaffe, A.B., 1989. Characterizing the "Technological Position" of Firms, with Application to Quantifying Technological Opportunity and Research Spillovers. Research Policy 18, 87-97.

Johnson-Laird, P.N., 1983. Mental Models. Cambridge University Press, Cambridge.

Kamakura, W.A., Russell, G.J., 1989. A Probabilistic Choice Model for Market Segmentation and Elasticity Structure. Journal of Marketing Research 26, 379-390.

Katz, M.L., Ordover, J.A., 1990. R\&D Cooperation and Competition. Brookings Papers on Economic Activity: Microeconomics, 137-203.

Killing, J.P., 1983. Strategies for Joint Ventures. Praeger, New York.

---- 1988. Understanding Alliances: The Role of Task and Organizational Complexity. Strategic Management Journal 9, 319-32.

Langlois, R.N., Robertson, P., 1992. Innovation in Modular Systems: Lessons from the Microcomputer and Stereo Component Industries. Research Policy 21, 297-313.

---- Robertson, P.L., 1995. Firms, Markets and Economic Change. Routledge, London.

Lewicki, R.J., Bunker, B.B., 1996. Developing and Maintaining Trust in Work Relationships. In R.M. Kramer and T.R. Tyler (eds.), Trust in Organizations: Frontiers of theory and research, 114-139. Sage Publications, Thousand Oaks.

McAllister, D.J., 1995. Affect- and Cognition Based Trust as Foundations for Interpersonal Cooperation in Organizations. Academy of Management Journal 38 (1), 24-59.

Mead, G.H., 1934. Mind, Self and Society -- From the Standpoint of a Social Behaviorist. Chicago University Press, Chicago.

Mowery, D.C., 1988. International Collaborative Ventures in US Manufacturing. Ballinger, Cambridge MA.

Nelson, R.R., Winter, S., 1982. An Evolutionary Theory of Economic Change. University Press, Cambridge.

Nooteboom, B., 1992. Towards a Dynamic Theory of Transactions. Journal of Evolutionary Economics 2, 281-99.

---- 1998. Cost, Quality and Learning Based Governance of Buyer-Supplier Relations. In M.G. Colombo (ed.), The Changing Boundaries of the Firm, 187-208. Routledge, London.

----- 1999. Interfirm Alliances: Analysis and Design. Routledge, London.

---- 2000. Learning and Innovation in Organizations and Economies. Oxford University Press, Oxford (paperback edition published in 2001). 
---- 2002. A Cognitive Theory of the Firm. Paper for a seminar on theories of the firm, November, Paris.

Ohmae, K., 1989. Global Logic of Strategic Alliances. Harvard Business Review (March/April), 143154.

Osborn, R.N., Baughn, C.C., 1990. Forms of Interorganizational Governance for Multinational Alliances. Academy of Management Journal 33 (3), 503-519.

Patel, P., Pavitt, K., 1997. The technological competencies of the world's largest firms: Complex and path-dependent, but not much variety. Research Policy 26, 141-156.

Pindyck, R.S., 1988. Irreversible Investment, Capacity Choice, and the Value of the Firm. American Economic Review 78, 969-985.

---- 1993. A Note on Competitive Investment under Uncertainty. American Economic Review 83, 273-277.

Pisano, G.P., 1990. The R\&D Boundaries of the Firm: An Empirical Analysis. Administrative Science Quarterly 35, 153-176.

Polanyi, M., 1966. The Tacit Dimension. Anchor Day Books, New York.

Porter, M.E. (ed.), 1986. Competition in Global Industries, 315-344. Harvard Business School Press, Boston, MA.

Powell, W.W., 1998. Learning from Collaboration: Knowledge and Networks in the Biotechnology and Pharmaceutical Industries. California Management Review 40 (3), 228-240.

----, Koput, K.W., Smith-Doerr, L., 1996. Interorganizational Collaboration and the Locus of Innovation: Networks of Learning in Biotechnology. Administrative Science Quarterly, 41, 116-145.

Sakakibara, M, 2002. Formation of R\&D Consortia: Industry and Company Effects. Strategic Management Journal 23 (11), 1033-1050.

Schein, E.H., 1985. Organizational Culture and Leadership. Jossey-Bass, San Francisco.

Schwarz, G., 1978. Estimating the Dimension of a Model. Annals of Statistics 6, 461-464.

Tversky, A., Kahneman, D., 1983. Probability, Representativeness, and the Conjunction Fallacy. Psychological Review 90 (4), 293-315.

Uzzi, B., 1997. Social Structure and Competition in Interfirm Networks: The Paradox of Embeddedness. Administrative Science Quarterly 42 (1), 35-67.

Vermeulen, F., Barkema, H., 2001. Learning through acquisitions, Academy of Management Journal, 44(3), 457-476.

Wedel, M., DeSarbo, W.S., 1994. A Review of Latent Class Regression Models and their Applications. In: Richard P. Bagozzi (ed.), Advanced Methods for Marketing Research, 353-388.

Weick, K.F., 1979. The Social Psychology of Organizing. Addison - Wesley, Reading, MA. 
---- 1995. Sensemaking in Organizations. Sage, Thousand Oaks CA.

Williamson, O.E., 1975. Markets and Hierarchies: Analysis and Anti-Trust Implications. The Free Press, New York.

---- 1985. The Economic Institutions of Capitalism -- Firms, Markets, Relational Contracting. The Free Press, New York.

Wuyts, S., Dutta, S., Stremersch, S., 2004. R\&D Agreement Portfolios in Technology Intensive Markets - Consequences for Innovation and Profitability. Journal of Marketing, Forthcoming.

Zucker, L.G., Darby, M.R., Armstrong, J.S., 2002. Commercializing Knowledge: University Science, Knowledge Capture, and Firm Performance in Biotechnology. Management Science 48 (1), 138-153.

---- , ----, Brewer, M.B., 1994. Intellectual Capital and the Birth of U.S. Biotechnology Enterprises. NBER Working Paper Series, No. 4653. 


\section{Publications in the ERIM Report Series Research* in Management}

\section{ERIM Research Program: "Organizing for Performance"}

2004

Learning And Governance In Inter-Firm Relations

Bart Nooteboom

ERS-2004-003-ORG

Organisational Learning And Multinational Strategy

Bart Nooteboom

ERS-2004-004-ORG

Density And Strength Of Ties In Innovation Networks: A Competence And Governance View Bart Nooteboom and Victor A. Gilsing

ERS-2004-005-ORG

Innovation, learning and cluster dynamics

Bart Nooteboom

ERS-2004-006-ORG

Empirical Tests Of Optimal Cognitive Distance

Stefan Wuyts, Massimo G. Colombo, Shantanu Dutta, and Bart Nooteboom ERS-2004-007-ORG

* A complete overview of the ERIM Report Series Research in Management: https://ep.eur.n//handle/1765/1

ERIM Research Programs:

LIS Business Processes, Logistics and Information Systems

ORG Organizing for Performance

MKT Marketing

F\&A Finance and Accounting

STR Strategy and Entrepreneurship 